DOI:10.1515/curie-2015-0034

\begin{tabular}{lcl}
\hline \multicolumn{1}{c}{ A N N A L E S } \\
UNiversitatis & MARIAE CURIE-SKŁODOWSKA \\
LUBLIN - POLONIA & \\
VOL. XXII, 2 & SECTIOK & 2015 \\
\hline
\end{tabular}

Wydział Studiów Międzynarodowych i Politycznych Uniwersytetu Jagiellońskiego

MAGDALENA M. KANIA

\title{
Biopolityczna przestrzeń bezpieczeństwa w Globalnej Wojnie z Terroryzmem
}

Biopolitical Spaces of Security in the Global War on Terror

\begin{abstract}
ABSTRAKT
Artykuł stanowi analizę przestrzeni bezpieczeństwa budowanej przez administrację amerykańską po 11 września 2001 r. przez pryzmat koncepcji biopolityki Michela Foucault. Celem artykułu jest wykazanie zależności między populacjo-centryczną biopolityką, praktykami liberalnej władzy a bezpieczeństwem. Przeanalizowano proces wzmacniania granic amerykańskich z wykorzystaniem biometrycznych technik zarządzania ryzykiem, tzw. Smart Borders, których celem jest redukcja negatywnych elementów z przestrzeni bezpieczeństwa.
\end{abstract}

Słowa kluczowe: biopolityka, Globalna Wojna z Terroryzmem, Smart Borders, sekurytyzacja granic

\section{WSTĘP}

Celem artykułu jest wykazanie współzależności między populacjo-centryczną koncepcją biopolityki, zgodnie z myślą francuskiego postmodernistycznego filozofa Michela Foucault ${ }^{1}$, praktykami liberalnej władzy mieszczącej się w ramach

\footnotetext{
1 Biopolityka jest definiowana w niniejszym artykule jako technika władzy polegająca na zarządzaniu populacjami, technika dyscyplinująca, regulująca, kontrolująca i administrująca, cechująca nowoczesność. Rozwój biopolityki skutkujący transformacją rdzenia polityki przez przeformułowanie koncepcji politycznej suwerenności był możliwy dzięki rozwojowi technologicznemu, wspomaganymi naukami o demografii. Dzięki stopniowo rozwijanym instrumentom statystyczno-poznawczym możliwe stało się gromadzenie danych na temat całej populacji i jej analizowanie w wymiarze czysto biologicznym. W ten sposób władza państwowa scalała w sobie wiedzę - władza jednocześnie produkowała wiedzę, jak rów-
} 
koncepcji governmentality ${ }^{2}$ (rządność) oraz bezpieczeństwem. Współzależność ta została przełożona na grunt Globalnej Wojny z Terroryzmem, prowadzonej przez administrację amerykańską po 11 września 2001 r., materializującej wszystkie czynniki w ramach biopolitycznych przestrzeni bezpieczeństwa. Jako przykład „punktów granicznych", w których przestrzeń bezpieczeństwa transformuje się w stronę biopolitycznej, w niniejszym artykule rozpatrzono kwestie kontroli granic po 11 września z wykorzystaniem biometrycznych technik zarządzania populacją, a w konsekwencji wytworzenie w ramach społeczeństwa kategorii ryzykownych populacji, traktowanej jako element negatywny w cyrkulacji bezpieczeństwa. Celem jest analiza włączenia stosowanych praktyk w szerszą narrację biopolityki, interwencyjnej polityki władzy nakierunkowanej na kontrolowanie i regulowanie populacji. Punktem wyjścia była koncepcja „przestrzeni bezpieczeństwa” zaproponowana przez Michela Foucault w wykładzie z 11 stycznia 1978 r. [2007: 48-56], w którym doszedł do konsolidacji technik, aparatów bezpieczeństwa (u Foucault jako dispositif) z populacją, pojawiającą się zarówno w formie przedmiotu, jak i podmiotu mechanizmów bezpieczeństwa.

Część pierwsza artykułu stanowi oś teoretyczną pracy, nakreślenie zależności między bezpieczeństwem, populacją a praktykami liberalnej władzy, materializującymi się w określonych przestrzeniach. Jej celem jest wydzielenie przestrzeni bezpieczeństwa jako osobnej kategorii ontologicznej, koegzystującej z przestrzeniami suwerenności czy dyscypliny. Celem jest również wykazanie, że dla transformacji ku biopolityce niezbędne jest działanie liberalnych praktyk władzy ukierunkowanych na całe populacje oraz wytworzenie specyficznych technik zarządzania populacją, by efektywnie manipulować cyrkulacją dóbr w ramach społeczeństw. Część druga artykułu jest analizą sytuacji Stanów Zjednoczonych po 11 września 2001 r. przez pryzmat wytworzenia specyficznych przestrzeni bezpieczeństwa - użycia technik nastawionych na kontrolę i nadzór całych populacji, nie pojedynczych ciał, celem administrowania i manipulowania cyrkulacją elementów skorelowanych $\mathrm{z}$ bezpieczeństwem. Przykładem poddanym analizie będzie działanie administracji amerykańskiej na poziomie zabezpieczenia granic państwowych, czego konsekwencją było zmaterializowanie przestrzeni biopolitycznego bezpieczeństwa $\mathrm{w}$ granicach terytorialnych, przez minimalizację cyrkulacji elementów negatywnych, m.in. ryzykownych jednostek, a maksymalizację pozytywnych. Mechanizmy bezpieczeństwa

nież była produkowana przez wiedzę $\mathrm{w}$ tym sensie, że wiedza z konieczności zakłada relacje władzy. Celem biopolitycznej władzy jest zapewnienie bezpieczeństwa rozumianego jako przetrwanie biologiczne populacji. Był to moment znaczącego przejścia; źródłem zainteresowania władzy przestała być jednostka z jej fizycznymi atrybutami (zainteresowanie o podłożu ekonomicznym - „tresura ciała” jednostki celem maksymalizacji produktywności i ekonomicznej efektywności), na rzecz społeczeństwa rozumianego jako całość, biologicznego ciała kolektywnego rządzącego się swoimi prawami [por. Foucault 1980, 1990, 1998, 2004, 2010, 2011].

2 Ze względu na niejednoznaczność terminu oraz brak ekwiwalentu językowego w artykule pozostanie niezmieniona wersja governmentality. Samo governmentality może być roboczo uznane za formę zdecentralizowanej władzy państwowej, jest jednak czymś w zakresie szerszym: jest nie tylko samą władzą, ale całą specyficzną sztuką rządzenia wykorzystującą konkretne liberalne praktyki i techniki. 
- odpowiedź liberalnej władzy na problem ostatecznie niepoznawalnych procesów wewnątrz populacji, która musi być regulowana i nadzorowana [Kienscherf 2013: 23] - jak zostanie wykazane, oparte były o sieć szeroko rozwiniętych technologii biometrycznych.

Z uwag wstępnych należy zaznaczyć, że Foucault nie zdefiniował jednolitej formy zarządzania bezpieczeństwem, skorelowanej z władzą polityczną; są to przynajmniej dwa układy technologiczne mechanizmów rządzenia. Pierwszym układem technologicznym będzie system dyplomatyczno-militarny [por. Foucault 2010: 287-312], drugą technologią będzie powiązana z suwerennością policja (polizeiwissenschaft) - wewnętrzne udoskonalenie racji stanu, której przedmiot zainteresowania pozostaje właściwie nieograniczony [Foucault 2011: 28-29] - podlegająca jednak ograniczeniom zewnętrznym, w tym prawnym. Celem policji jest regulowanie wszystkich form zachowania dyscypliną. Tym samym policja jako aparat mający przylegać w całości do społeczeństwa, ,nie tylko do ekstremalnych wyskoków”, reprezentuje dyscyplinarną sieć bazującą na permanentnym, kompletnym, wszechobecnym i niewidzialnym nadzorze [Foucault 1998: 208]. Jest złożoną siecią politycznych analiz technologicznych, wzajemnych powiązań, która monitoruje i kontroluje populacje [Herbert 1996: 48]. Porządkiem sprawowania władzy jest omawiane w artykule liberalne governmentality działające w sferze bezpieczeństwa, które tym jest odmienne od policji, że szuka własnej i miary, i ograniczeń w dziedzinach faktycznego życia [Dillon 2007: 42], postrzegając wolność jednostki jako konieczność swojej działalności [Hindess 2005: 394].

\section{MIEJSCE GOVERNMENTALITY W PRZESTRZENIACH WŁADZY}

Abstrakcyjnie ujmowana problematyka przestrzeni władzy ma charakter kompleksowy, co wyraża się w wielopoziomowej analizie, nie tylko w kontekście statycznym, rozumianym tu jako geograficzny, ale również na poziomie cyrkulacji dóbr, zasobów, celów, a także faktycznych działań i wpływów. Pierwotna dystynkcja przestrzeni władzy, zgodnie z logika Foucault [2007: 48], nie tyle stanowi o rozgraniczeniu, co raczej dopełnianiu się i ich wzajemnym nachodzeniu. Nakreśla ona przestrzenie wyznaczane: przez suwerenność, która definiuje przestrzeń jako terytorialne granice $^{3}$, w których się osadza, przez dyscyplinę, której obszar rozprzestrzenia się w ciałach poszczególnych jednostek oraz przez bezpieczeństwo, którego obszarem przestrzennym są całe populacje.

Suwerenność jest wpisana ze swej istoty w konkretnie definiowane terytorium, co więcej sama idea suwerenności pozwala jej w abstrakcyjnej formie pozostawać politycznie i jurydycznie akceptowalną ideą, nawet gdy odnosi się do niezamieszka-

3 Stąd dla Foucault dobrym suwerenem będzie ten suweren, który jest dobrze osadzony wewnątrz terytorium. 
łego terytorium. Z geograficznego punktu widzenia konstytuuje terytorium, w ramach którego działa. Dla politycznej efektywności musi pozostawać w relacji do określonej wielości podmiotów - społeczeństwa w ramach terytorium, nad którym sprawuje władzę i nad którym włada cyrkulacją określonych dóbr - idei, woli, rozkazów, handlu. Z kolei dyscyplina materializuje się w przestrzeni ciał jednostek, do których się odnosi. Co do zasady jest ona teleologiczna, i jako siła zarządzająca i organizująca wielość raczej indywidualizuje uprzednio daną grupę niż wyrasta jako jedność powstała z wielości jednostek [Foucault 1998: 49]. Dyscyplina sprowadza ciało do „natarczywego i zadecydowanego blokowania”, nie tyle przez ujmowanie w sieć zakazów, zobowiązań i przymusów, co również przez skalę kontroli - ciało pozostaje pod wpływem wywieranego nań przymusu, które jest działaniem czysto mechanicznym, nieprzerwanym, nieustannym, nacelowany raczej na przebieg czynności niż jej wynik, także w konsekwencji ciałom narzucana jest relacja „podatność-przydatność” [Foucault 1998: 132-133]. O ile suwerenność kapitalizuje przestrzeń, o tyle dyscyplina ją strukturyzuje oraz wyznacza problemy hierarchicznej i funkcjonalnej dystrybucji elementów [Foucault 2007: 55]. Z tej perspektywy - operowania wyłącznie w kontekście wielości elementów, z którymi pozostaje w relacji - dyscyplina wymaga tego samego środowiska, co bezpieczeństwo czy suwerenność. Rozróżnienie polega na tym, że gdy dyscyplina operuje przez zawieranie w zamknięty krąg elementów, na które oddziałuje, bezpieczeństwo wymaga otwartego kręgu, w którym działa, by umożliwić maksymalnie efektywną cyrkulację określonych dóbr [Elden 2007: 30]. Jak zauważył Collin Gordon [1991: 36], otwarte kręgi cyrkulacyjne bezpieczeństwa koherentnie wyznaczają liberalne bezpieczeństwo, które pozostaje w relacji również z elementami pozostającymi poza jego zakresem. Dyscyplina określa się w ścisłych ramach między tym co dozwolone a co zabronione, jednocześnie dookreślając nakaz, nie dookreślając zakazu, natomiast esencjalną funkcją bezpieczeństwa - ani niezakazującą, ani nienakazującą - jest możliwe wykorzystanie niektórych instrumentów nakazów i zakazów jako taktyk odpowiadających na zmieniającą się dynamikę rzeczywistości - w efekcie anulując ją, powstrzymując i regulując [Foucault 2010: 68-69].

Ontologicznie bezpieczeństwo jest zależne od zastanych elementów, dóbr, polega na maksymalizowaniu pozytywnych elementów, co do których zarządzający bezpieczeństwem organizują możliwie najlepszą cyrkulację, a jednocześnie na minimalizowaniu tych współczynników, które niosą ryzyko i dyskomfort (m.in. choroby, kradzieże). Te drugie nigdy nie zostaną wyeliminowane, mogą być jedynie redukowane, stąd zarządzający bezpieczeństwem pracują zawsze w sferze możliwości [Foucault 2010: 54]. Działania podejmowane przez zarządzających bezpieczeństwem nie są zatem w prostym rozumieniu odpowiedzią na zastane zagrożenia, a raczej nadawaniem takim elementom formy, według której powinny być one postrzegane jako immanentne dla praktyk i racjonalności liberalnego governmentality [Kienscherf 2013: 19]. Podsumowując, problem bezpieczeństwa to problem serii - niezdefiniowanej serii mobilnych elementów oraz równorzędnie serii akumulujących się jednostek. Zarządzanie tymi seriami może być kontrolowane jedynie przez oszacowanie prawdopodo- 
bieństw - przestrzeń bezpieczeństwa odnosi się do serii możliwych zdarzeń, wydarzeń tymczasowych i niepewnych, które muszą być włożone w daną zmaterializowaną przestrzeń. Przestrzeń ta, nieograniczona przez zdefiniowane uprzednio terytorium, prowadzi do zacierania granic między dychotomią cechującą klasyczne studia nad bezpieczeństwem analizowanym w dwójnasób, bądź jako studium wewnętrznie pacyfikowanego terytorium, bądź jako anarchiczna sfera stosunków międzynarodowych [Kienscherf 2013: 16]. Wyłączając czynnik terytorialny z przestrzeni bezpieczeństwa, Foucault zatarł dychotomię między tym co wewnętrzne a tym co zewnętrzne, wychodząc poza dystynkcję między bezpieczeństwem wewnętrznym a zagraniczną obroną.

Podstawową kategorię u Foucault, odnoszącą się do zarządzających bezpieczeństwem, stanowi aparat/mechanizm bezpieczeństwa rozumiany jako „mechanizm rządowy", kompleksowe mechanizmy składające się z komponentów ekonomicznych, jednostek politycznych, elementów dyskursywnych oraz socjokulturowych informacji, które konsolidują się dla celów strategicznych [Debrix, Barder 2012: 60]. Mechanizmy bezpieczeństwa tworzą, fabrykują, organizują i rozplanowują środowisko (milieu) rozumiane jako przestrzeń naturalnie danych i sztucznie wytworzonych elementów, w której ma miejsce cyrkulacja dóbr. Ostatecznie środowisko to konstytuuje się jako pole interwencji, w którym zamiast bezpośredniego oddziaływania na jednostki, jako zespół prawnych podmiotów zdolnych do podejmowania opartych na woli działań (co byłoby zasadne w kontekście suwerenności), ciał zdolnych i zmuszanych do działania (kontekst dyscypliny) - zarządzający bezpieczeństwem wpływa bezpośrednio na populację rozważaną $\mathrm{w}$ aspekcie biopolitycznym, jako istniejącą biologicznie i powiązaną ze światem materialnym, w którym żyje [Foucault 2007: 54-56].

Zarządzającym bezpieczeństwem jest rząd, aparat zarządzania ciałami, życiami i dobrostanem - governmentality. Governmentality to zarządzanie serią cyrkulacji w przestrzeniach społecznych, w obrębie których chodzi nie o narzucanie praw ludziom, ale o kierowanie rzeczami, stosowanie taktyk i technik, by za ich pomocą realizować określone cele przy użyciu określonych środków [Foucault 2010: 116-117]. Rozumiejąc governmentality jako całość relacji władzy, na którą składają się zespoły instytucji, procedur, analiz, refleksji, kalkulacje i taktyki, dzięki którym możliwe jest działanie kompleksowo rozumianej władzy, Foucault wpisał governmentality w istotę państwa nowoczesnego; państwo per se traktowane jest jako relacyjna całość [Jessop 2006: 37]. Governmentality jest w tym sensie projektem władzy liberalnej, że prowadzi do konwergencji procesów regulacji populacji przez władzę z liberalnymi praktykami kapitalizmu [Medovoi 2007: 57]. Liberalność rządu przejawia się w jego działaniu, charakteryzującym się utylitarnością oraz umiarkowaniem - liberalne governmentality nakłada na siebie regulacje i dokonuje autoewaluacji na podstawie zmian $w$ rozumieniu narastających procesów naturalnych, którymi rządzi [Dillon 2007: 42], jest rodzajem rządu opartym na efektywności, gdzie substytutem legitymizacji jest sukces. Korelatem stosowanego w obrębie governmentality aparatu bezpieczeństwa jest liberalnie pojmowana wolność - aparat bezpieczeństwa nie funkcjonuje efektywnie w środowisku, w którym nie ma danej uprzednio wolności rozumianej w nowoczesnym ujęciu jako 
wolności przemieszczania się, procesu przepływu ludzi i rzeczy. Wolność przepływu, cyrkulacja, stanowią jądro wolności, jednocześnie kluczowy aspekt efektywności aparatu bezpieczeństwa [Foucault 2010: 71]. Bezpieczeństwo rozciągane przez liberalne governmentality pojawia się tutaj kontrastująco do powszechnego założenia o napięciach na linii bezpieczeństwo-wolność i powinno być postrzegane jako nierozerwalnie splecione z wolnością [por. Neocleous 2008: 11-38]. Liberalizm i mechanizmy bezpieczeństwa $w$ tym sensie stanowią odpowiedź na ostatecznie niezdolne do poznania procesy wewnątrz populacji, które mimo wolności muszą być regulowane i kontrolowane [Kienscherf 2013: 22].

Liberalne rządy nad populacją $\mathrm{w}$ zakresie bezpieczeństwa opierają się przede wszystkim na rozgraniczeniu między tym co rządzone może być w sposób liberalny a tym co wymaga nieliberalnych praktyk - rosnącą liczbę działań państwowych w zakresie m.in. wydawania podejrzanych o terroryzm w trybie nadzwyczajnym (extraordinary renditions), zatrzymania na czas nieokreślony (indefinite detentions), nowych praktyk i technologii kontroli granic państwowych czy kwestie związane z prawem imigracyjnym [por. Bigo, Tsoukala 2008; Guild, Groenendijk, Carrera 2009; Hindess 2001; Hindess 2004]. Wynika to z założenia, że liberalne rządy opierają się na wolnym wyborze jednostki, który rozumiany jest jako odpowiedzialność jednostki za wybory tak długo, jak niezakłócony zostaje porządek społeczny. „Nieliberalna praktyka” rządu odnosi się do sytuacji legitymizowanego użycia siły przymusu przez liberalne państwo w stosunku do jednostek, których działanie stanowi zakłócenie bezpieczeństwa-wzmaga cyrkulację negatywnych elementów w logice Foucault - dla wykonywania wolnej woli jednostek podległych porządkowi społecznemu [Corva 2008: 177]. Pierwotna dystynkcja liberalnej władzy leży w podziale na tych, którzy rządzeni będą w liberalny sposób lub autorytatywnie, lub ostatecznie tych, którzy zakłócając liberalny porządek, muszą zostać z niego wykluczeni [Hindess 2004: 28]. W tym miejscu, zdaniem Markusa Kienscherfa [2013: 25], dochodzi do lokacji suwerenności wewnątrz zdecentralizowanego governmentality w polu bezpieczeństwa - suwerenność staje się zdecentralizowana w tym sensie, że przenika wszystkie aspekty społeczne, manifestuje się w różnych formach mechanizmów bezpieczeństwa, które nacelowane są na rozgraniczenie „,bezpiecznych" i ,niebezpiecznych" jednostek w populacji. Mając na celu utworzenie liberalnego porządku, liberalna władza przez nieliberalne praktyki produkuje i reprodukuje populacje elastyczne, łatwe do oddziaływania, jednocześnie wykorzeniając te jednostki, które uznaje oporne na liberalne rządy [Kienscherf 2013: 32].

\section{SMART BORDERS JAKO PRODUKCJA BIOPOLITYCZNEJ PRZESTRZENI BEZPIECZEŃSTWA PO 11 WRZEŚNIA}

Atak 11 września 2001 r. na World Trade Center, jak zauważa Julian Reid [2006: 95], jest wydarzeniem symbolicznym ze względu na to, że jawi się nie tyle jako atak na ikonę liberalnej współczesności, co raczej atak na rozsypujący się posąg 
pewnej formy społeczeństwa. Według Zygmunta Baumanna okres po 11 września to ,przerażające doświadczenie heteronomicznych, podatnych na bodźce populacji przytłoczonych siłami, których ani nie kontrolują, ani nie całkiem rozumieją, przerażonych własną niezdolnością do obrony i obsesyjnie nastawionych do bezpieczeństwa swoich granic" [Baumann 2006: 96]. Atakiem tym rozpoczęła się Globalna Wojna z Terroryzmem (GWOT) - przestrzennie i czasowo nieokreślona kampania pacyfikacyjna ${ }^{4}$, której celem są nie tyle jednostki, co całe populacje. GWOT wpisuje się w schemat sekurokratycznych wojen bezpieczeństwa publicznego Allena Feldmana [2004: 330-350], tj. nie jest ani ukierunkowana na podboje terytorialne, ani prowadzona przeciw łatwym do namierzenia w sensie lokacyjnym wrogom $\mathrm{z}$ roszczeniami terytorialnymi, natomiast skierowana jest na przeciwdziałanie narzucanej terytorialnej kontaminacji i transgresji: terrorystycznej, demograficznej czy biologicznej infiltracji. Innymi słowy, minimalizowanie w obiegu cyrkulacyjnym w zakresie bezpieczeństwa elementów postrzeganych jako negatywne.

Poczucie zagrożenia odczuwalne w zachodnim stylu życia, utożsamianym z liberalnymi wartościami i wolnościami, podlegało operacjonalizacji w dyskursie politycznym w Stanach Zjednoczonych po 11 września, w którym Al Kaida, rosnąc do rangi symbolu międzynarodowego terroryzmu, sukcesywnie była ujmowana w ramy jako zagrożenie egzystencjalne całych populacji, natomiast Stany Zjednoczone określały swoją pozycję jako globalnego obrońcę liberalnych wartości w systemie międzynarodowym [Singh 2015: 110]. Takie ramowanie zagrożenia pozwalało wychodzić poza tradycyjną linię oddzielającą bezpieczeństwo wewnętrzne od zewnętrznego - specyfika wojny prowadzonej przeciw rozproszonemu wrogowi, niebazującemu na specyficznie określonym terytorium, zmniejsza rangę czynnika terytorialnego. Omawiana w niniejszym artykule kontrola granic jest nie tylko ochroną geograficzną danego terytorium, lecz także ma wymiar nadzorowania oraz manipulowania cyrkulacją elementów pozytywnych i negatywnych w ramach społeczeństw - w przestrzeni materializującej się w populacjach. Materializacja w populacjach jest związana z masowym przepływem ludzi przez granice państwowe, zarówno jednostki napływające, jak i odpływające, tym samym skupiają one na sobie całą uwagę aparatu bezpieczeństwa, poszerzając przestrzeń, która definiowana wyłącznie granicami państwowymi, odnosiłaby się do geograficznie danego terytorium. Doświadczenie tradycyjnego rozumienia granic transformuje się w stronę bardziej „wirtualnych granic” [Muller 2009: 68]. Tym samym mechanizmy bezpieczeństwa wymagają do funkcjonowania wolności - wolności przypływu elementów. Negatywnymi elementami od strony przedmiotowej zostaną uznane akty terrorystyczne, od strony podmiotowej - ryzykowne jednostki, co do których istnieje podejrzenie - zasadne bądź szacowane - działalności terrorystycznej.

4 Explicite prezydent George W. Bush w przemówieniu 20 września 2001: „Our war on terror begins with Al Qaeda, but it does not end there. It will not end until every terrorist group of global reach has been found, stopped and defeated" [Bush 2001]. 
Pierwszym elementem stworzenia środowiska do materializacji oraz zarządzania przez liberalną władzę cyrkulacją $\mathrm{w}$ ramach przestrzeni bezpieczeństwa będzie wytworzenie ram postrzegania negatywnych elementów, by zakwalifikować je jako wrogie, egzystencjalnie nieprzyjazne względem środowiska. Wrogi element narasta w kontekście antagonizującego dyskursu władzy produkującej tym samym konkretną formę inności [Debrix, Barder 2012: 90-91], co dla Carla Schmitta było wyznacznikiem wroga politycznego - egzystencjalna inność, obcość leżąca w jego naturze w sposób zintensyfikowany [Schmitt 2007: 27]. W dyskurs polityczny narastający po 11 września wprowadzono zasadnicze rozróżnienie pomiędzy zwykłym wrogiem (normal enemy), czyli takim, który działa w sposób przewidywalny, wpisując się jednocześnie w mentalny krajobraz istniejącego politycznego wyobrażenia, a wrogiem absolutnym (absolute enemy), który zagraża całemu wyobrażonemu krajobrazowi [Buck-Morss 2008: 145]. Zasadniczość tej dystynkcji nabiera znaczenia w kontekście zarządzania cyrkulacją dóbr w przestrzeniach bezpieczeństwa - zarządzający bezpieczeństwem operują wyłącznie w sferze możliwości, szacunków, prawdopodobieństw i sytuacji niemożliwości całościowej redukcji negatywnych efektów; istotne $\mathrm{z}$ tego punktu widzenia będzie więc stopniowanie wartości przypisywanych poszczególnym elementom oraz takie zarządzanie cyrkulacją, by w najpełniejszym stopniu minimalizować elementy uznane za skrajnie negatywne. Tym samym liberalna władza, opierając się na mechanizmach bezpieczeństwa, tworzy, fabrykuje i rozplanowuje środowisko, w którym operuje. Logika biopolitycznej perspektywy wrogości, oczyszczająca liberalne społeczeństwa, populacje, z nieliberalnych elementów, prowadzi w konsekwencji do strącenia tych drugich w stronę destrukcji przypisanej wrogiemu innemu ${ }^{5}$ [Debrix, Barder 2012: 103].

Wytyczanie granic stanowi znaczący moment w formowaniu państwowości, pierwotną bowiem rolą granic było odgradzanie terytorium, nad którym dana władza sprawowała kontrolę, od terytorium innych podmiotów politycznych oraz od strefy międzynarodowej - funkcją granic byłoby zatem materializowanie abstrakcyjnego rozróżnienia między tym co włączone a wyłączone $\mathrm{z}$ wyobrażonej wspólnoty [Kienscherf 2013: 90-91]. W kontekście liberalizacyjnych tendencji nowoczesności otwierania granic oraz uregulowań prawa międzynarodowego, rozciągającego zakres podmiotowy na obywateli różnych państw, rola granic znacznie słabnie. 11 września był dla Stanów Zjednoczonych punktem kulminacyjnym napięcia między, z jednej strony, ekonomiczną presją otwierania granic $\mathrm{z}$ żądaniami nieskrępowanego przepływu kapitału, dóbr, usług i w mniejszym stopniu osób (w kontekście NAFTA), a z drugiej strony, geopolitycznymi żądaniami zamykania granic w imię bezpieczeństwa wewnętrznego [Sparke 2006: 152]. Pokłosiem ataków terrorystycznych, według Benjamina Mullera [2009: 67], było wytworzenie sytuacji, w której nawet granice, tj.

5 W tym kontekście biopolityka, nastawiona na życie, nie na śmierć, transformuje się w stronę tanatopolityki czy nekorpolityki - prądom nakierunkowanym na śmierć. Koncepcja ta jest szerzej rozwijana przez Roberto Esposito czy Achille Mbembe [por. Esposito 2004; Mbembe 2003]. 
będąca przez długie dziesięciolecia przedmiotem dumy najdłuższa nieobroniona granica świata pomiędzy Kanadą a Stanami Zjednoczonymi, doświadczają nadmiernego zaabsorbowania praktykami wykluczenia, szkodliwej aplikacji zarządzania ryzykiem, rozwinięcia biometrycznych technologii skupionych na zarządzaniu tożsamościami, w rezultacie zostają one poddawane sekurytyzacji.

Po 11 września bezpieczeństwo na granicy amerykańsko-kanadyjskiej zostało wpisane - początkowo z inicjatywy amerykańskiej, następnie rozwijane także przez stronę kanadyjską - w model zarządzania ryzykiem (risk management). Przyjmując ten model jako podstawową strategię zarządzania bezpieczeństwem na granicach, administracja w imię bezpieczeństwa publicznego, jako technikę władzy wykorzystała rządzenie przez ryzyko (governing through risk) [Aradau, Munster 2007; Muller 2008]. Ryzyko nie jest w tym rozumieniu czymś, co pochodzi z zewnątrz, spoza granic, ale jest produkowane przez wpływ rozwijającej się wiedzy na podstawie świata [Ceyhan 2008: 105], jest zarządzaniem oraz szacowaniem niekalkulowanymi elementami tworzącymi ryzyko, opartym na logice zarządzania niepewnością [de Goede 2008]. Zarządzanie ryzykiem na granicach jest poddane, za Benjaminem Mullerem [2007: 68], trzem trendom: 1) kwantyfikacji bezpieczeństwa, która operuje w przestrzeni wyobrażonych liczb [Salter 2008]; 2) związanej z poprzednim trendem technologizacji bezpieczeństwa; 3) centralizacją władz.

Natychmiastową reakcją władz amerykańskich na wydarzenia 11 września było wzmocnienie granic. Militaryzacja bezpieczeństwa na granicach doprowadziła do znaczących opóźnień w ruchu granicznym z Kanadą oraz Meksykiem, co w szczególności skutkowało negatywnymi konsekwencjami dla ekonomii [Sparke 2006: 161-162]. 12 grudnia 2001 r. rządy Kanady i Stanów Zjednoczonych przyjęły dokument „Smart Border Declaration"6, umożliwiający wdrożenie praktyk zarządzania przepływającymi masami ludzi przez użycie technik biometrycznych. Smart Borders, jako systemy weryfikacji biometrycznej, zostały zaprojektowane jako systemy inwigilacyjne z zasadniczą funkcją ochrony dostępu do konkretnych przestrzeni - zarówno fizycznych, jak i logistycznych - oparte na zarządzaniu ryzykiem w taki sposób, by zmniejszyć możliwości penetracji uprzednio definiowanej jako bezpiecznej strefy przez nieautoryzowane, niepożądane elementy [Epstein 2008: 180]. Systemy te opierały się na bazach danych biometrycznych całych populacji, których zamiarem było włączenie się do stref bezpieczeństwa. Implikacją tych porozumień było powstanie serii programów biometrycznych na granicach wdrażających strategie zarządzania niepewnym ryzykiem, m.in. „Trusted Traveler Programs”. Przyjęte programy to rozwinięty na granicy amerykańsko-kanadyjskiej NEXUS/NEXUS AIR, na granicy amerykańsko-

6 Pełna nazwa: Smart Border Declaration and Associated 30-Points Action Plan to Enhance the Security of Our Shared Borders While Facilitating the Legitimate Flow of People and Goods, rozszerzona później w 2002 r. 
meksykańskiej ${ }^{7}$ SENTRI $^{8}$, przeznaczony do międzynarodowych podróży Global Entry czy odnoszący się do importu towarów handlowych na granicach amerykańskich FAST. Logikę zarządzania ryzykiem przyjęły także programy Secure Flight, Passenger Protect w powiązaniu z ustaloną przez administrację amerykańską No Fly List.

Programy Trusted Traveler, mające na celu przyspieszenie procesów odprawy granicznej dla wcześniej zatwierdzonych obywateli stanowiących niski stopień ryzyka dla bezpieczeństwa państwa, działają na podstawie tego samego schematu - jednostki zapisane do programu, które wcześniej zostały zakwalifikowane jako niestanowiące zagrożenia, muszą posiadać przy sobie odpowiednie karty zawierające dane biometryczne, które następnie są odtwarzane na ekranie osoby odpowiedzialnej za kontrolę, tożsamość jest sprawdzana przez biometryczną weryfikację, np. prześwietlenie tęczówki, jak w przypadku NEXUS AIR. Mark Salter, odnosząc się do nakładania biometrycznych systemów na obce jednostki, które chcą przedostać się do Stanów Zjednoczonych, stwierdził, że tym zabiegiem amerykańska administracja prowadzi do bezpośredniej transformacji biometryki w globalną normę bezpieczeństwa [Salter 2006]. System zbierający dane od początku GWOT ulegał technicznym udoskonaleniom oraz rozwojowi - od 2002 r. był to program NSEER ${ }^{9}$, następnie został zastąpiony przez US-VISIT ${ }^{10} \mathrm{w} 2003$ r., który z kolei w 2013 r. został przekształcony w Office of Biometric Identity Management. W rzeczywistości programy te wprowadzały podwójne standardy traktowania populacji - wydzielenie tych elementów z populacji, które są pozytywne bądź neutralne, oraz tych, które stanowią zagrożenie dla cyrkulacji bezpieczeństwa. Jak zauważył Matthew Sparke [2006: 173-174], całe populacje podzielono na „kinetyczną elitę” (często podróżujący, podróżujący bez kolejek, klasyfikowani przez system jako niegroźni) oraz „kinetyczną podklasę"

Dla governmentality biometryka stanowi jedną z podstawowych technik zarządzania bezpieczeństwem nakierunkowaną na całe populacje. Charlotte Epstein [2008: 184] stwierdziła, że systemy biometryczne są konstytuowane wokół dwóch osi: dyscypliny oraz biopolitycznego bezpieczeństwa. Od strony biopolitycznej zawierają w sobie każdą większą populację podróżujących, od strony dyscypliny nieustannie zwiększają zdolność do lokowania indywidualnych ciał, czego konsekwencją jest konstytuowanie obcych ciał (foreign bodies). W tym sensie granice stały się dla governmentality punktem rozwoju nowych technologii zarządzania populacji.

\footnotetext{
7 Problem wzmacniania kontroli na granicy amerykańsko-meksykańskiej jest dużo bardziej złożony niż w przypadku granicy z Kanadą - zdecydowane działania wzmacniania granic były przeprowadzone już w latach 90. XX w. [por. Purcell, Nevins 2005].

8 Pełna nazwa: Secure Electronic Network for Travelers Rapid Inspection.

9 Pełna nazwa: National Security Entry-Exit Registration. Niektóre narodowości były automatycznie włączone w rejestrację: Irak, Iran, Libia, Sudan, Syria. Później włączono także: Afganistan, Algierię, Arabię Saudyjską, Bahrajn, Bangladesz, Egipt, Erytreę, Indonezję, Jemen, Jordanię, Koreę Północną, Kuwejt, Liban, Maroko, Oman, Pakistan, Katar, Somalię, Tunezję oraz Zjednoczone Emiraty Arabskie.

10 Pełna nazwa: United States Visitor and Immigration Status Indicator Technology.

11 Koncepcja „elit kinetycznych” pojawia się również u Petera Adeya [por. Adey 2006].
} 
Nie są jednak wyłącznie fizycznym wzmocnieniem barier, są elastyczne, oparte na wysokich technologiach. Nie są też klasycznymi „bramami” dla suwerenności, w których władza jest rozciągana przez pozwalanie bądź odmawianie dostępu do bram, ale jednocześnie władza nie sięga dalej niż poza bramy - granice stały się bramami władzy rozciągającej się na obce populacje, wykraczające poza geograficzne granice, zmieniły się w strategiczne przestrzenie zbierania danych biometrycznych, w które inwestuje governmentality [Epstein 2008: 185].

\section{ZAKOŃCZENIE}

Celem minimalizowania niepożądanych skutków cyrkulacji negatywnych elementów w ramach populacji, zaburzających dotychczasowy porządek, liberalne governmentality wykorzystuje złożony system mechanizmów bezpieczeństwa, tworząc w konsekwencji biopolityczną przestrzeń bezpieczeństwa. Przedstawione w poprzedniej części zarządzanie ryzykiem, obecne na granicach amerykańskich po 11 września, włącza praktykę władzy w logikę produkowania przestrzeni bezpieczeństwa w rozumieniu biopolitycznym. Bezpieczeństwo z jednej strony wymaga uprzednio danej wolności, co materializuje się w masowym przepływie swobód między granicami, w tym co najbardziej istotne, masowym przepływie osób. Zapewnia to stałą cyrkulację elementów w przestrzeniach zarządzanych przez władzę. Jednocześnie cyrkulacja ta poddawana jest nieustannej kontroli, nadzorowi, w konsekwencji czego jest wtórnie reprodukowana przez redukcję elementów negatywnych. Zgodnie z logiką Foucault, całkowita eliminacja elementów negatywnych jest niemożliwa, pozostaje jedynie $\mathrm{w}$ sferze idealistycznej, zadaniem zarządzających bezpieczeństwem jest szacowanie, które elementy mogą być uznane za konieczne do redukcji i wyłączone z obiegu bezpieczeństwa. Przekładając teoretyczne rozważania na grunt amerykański, widoczne staje się, że opracowanie Smart Borders wychodzi naprzeciw założeniom złączenia bezpieczeństwa z presją ekonomicznej wolności. Kontroli i nadzorowi poddawane są całe populacje, nie zawsze związane ściśle z geograficznie danym terytorium, przekraczające granice, doświadczające praktyk bezpieczeństwa przez kontrolowanie, ewidencjonowanie i kwantyfikację. Gromadzenie baz danych, ich analiza, przetwarzanie i reprodukowanie, a także wykorzystywanie technologii odsłaniają esencję biopolityki - biopolityki w swym najprostszym rozumieniu, jako interwencji oraz regulacyjnej kontroli populacji, kalkulację zarządzania życiem. Zależność między bezpieczeństwem, populacją a liberalnym governmentality - działającym przez kompleks heterogenicznych sieci praktyk - stanowi nierozerwalną całość, w której jeden czynnik jest jednocześnie warunkiem i konsekwencją istnienia kolejnych. Specyfika GWOT jako biopolitycznej przestrzeni materializuje się w skali przedsięwzięcia zarządzania bezpieczeństwem rozciąga się ponad terytorium, ponad populację, którą stanowią wyłącznie obywatele Stanów Zjednoczonych. Przestrzeń governmentality w GWOT dyscyplinuje system 
międzynarodowy w kierunku zgodności z wartościami liberalnymi, rozciągając się na przestrzeni rzekomo suwerennych terytoriów, a gdy zgoda na liberalny porządek jest nieobecna, rości sobie prawo do wyłączania populacji z przestrzeni bezpieczeństwa [Roberts 2010: 37].

\section{BIBLIOGRAFIA}

Adey, P. 2006. "Divided We Move": The Dromologics of Airport Security and Surveillance, [w:] Surveillance and Society: Technological Politics and Everyday Life, T. Monahan (red.), Routledge, Nowy Jork.

Aradau, C. Munster, Van R. 2007. Governing Terrorism through Risk: 2. Taking Precautions, (un)Knowing the Future, "European Journal of International Relations", t. 13, nr 1, http://dx.doi.org/doi:10.1177/1354066107074290.

Baumann, Z. 2006. Liquid Fear, Polity, Cambridge.

Bigo, D., Tsoukala, A. 2008. Understanding (In)Security, [w:] Terror, Insecurity and Liberty: Illiberal Practices of Liberal Regimes after 9/11, D. Bigo, A. Tsoukala (red.), Routledge, Londyn, Nowy Jork.

Buck-Morss, S. 2008. Sovereign Right and the Global Left, "Cultural Critique", t. 69, http://dx.doi.org/doi:10.1353/cul.0.0005.

Bush, G.W. 2001. Address to a Joint Session of Congress and the American People, http://georgewbush-whitehouse.archives.gov/news/releases/2001/09/20010920-8.html (dostęp: 21.11.2015).

Ceyhan, A. 2008. Technologization of Security: Management of Uncertainty and Risk in the Age of Biometrics, "Surveillance \& Society", t. 5, nr 2.

Corva, D. 2008. Neoliberal Globalization and the War on Drugs: Transnationalizing Illiberal Governance in Americas, "Political Geography", t. 27, nr 1, http://dx.doi.org/doi:10.1016/j.polgeo.2007.07.008.

De Goede, M. 2008. The Politics of Preemption in the War on Terror, "European Journal of International Relations", t. 14, nr 1, http://dx.doi.org/doi:10.1177/1354066107087764.

Debrix, F., Barder, A.D. 2012. Beyond Biopolitics. Theory, Violence and Horror in the World Politics, Routledge, Abington.

Dillon, M. 2007. Governing through Contingency: The Security of Biopolitical Governance, "Political Geography", t. 26, nr 1, http://dx.doi.org/doi:10.1016/j.polgeo.2006.08.003.

Elden, S. 2007. Rethinking Governmentality, "Political Geography", t. 26, nr 1, http://dx.doi.org/doi:10.1016/j.polgeo.2006.08.001.

Epstein, Ch. 2008. Embodying Risk. Using Biometrics to Protect Borders, [w:] Risk and the War on Terror, L. Amoore, M. de Goede (red.), Routledge, Abington.

Esposito, R. 2004. Bios: Biopolitics and Philosophy, University of Minnesota Press, Minneaopolis.

Feldman, A. 2004. Securocratic Wars of Public Safety. Globalized Policing and Scopic Regime, "Interventions: The International Journal of Postcolonial Studies", t. 6, nr 3, http://dx.doi.org/10.1080/1369801042000280005.

Foucault, M. 1980. Body/Power, [w:] Power/Knowledge. Selected Interviews and Other Writings 19721977, C. Gordon (red.), Harvester Wheatsheaf, Londyn.

Foucault, M. 1990. History of Sexuality. Vol. 1: An Introduction, Vintage Books, Nowy Jork.

Foucault, M. 1998. Nadzorować i karać. Narodziny więzienia, Aletheia, Warszawa.

Foucault, M. 2004. Society Must Be Defended. Lectures at the Collegé de France 1975-76, Penguin Books, Londyn.

Foucault, M. 2007. Spaces of Security: The Example of a town. Lecture of 11th January 1978, "Political Geography", t. 26, nr 1, http://dx.doi.org/doi:10.1016/j.polgeo.2006.08.004.

Foucault, M. 2010. Bezpieczeństwo, terytorium, populacja. Wyklady w Collegé de France 1977-1978, Wydawnictwo Naukowe PWN, Warszawa. 
Foucault, M. 2011. Narodziny biopolityki. Wyklady w Collegé de France 1978-1979, Wydawnictwo Naukowe PWN, Warszawa.

Gordon, C. 1991. Governmental Rationality, [w:] The Foucault Effect. Studies in Governmentality, G. Burchell, C. Gordon, P. Miller (red.), University of Chicago Press, Chicago.

Guild, E., Groenendijk, K., Carrera, S. 2009. Understanding the Contest of Community: Illiberal Practices in the EU? [w:] E. Guild, K. Groenendijk, S. Carrera, Illiberal Liberal States. Immigration, Citizenship and Integration in the EU, Ashgate, Surrey.

Herbert, S. 1996. The Geopolitics of the Police: Foucault, Disciplinary Power and the Tactics of the Los Angeles Police Department, "Political Geography", t. 15, nr 1.

Hindess, B. 2001. The Liberal Government of Unfreedom, "Alternatives", t. 26, nr 2, http://dx.doi.org/doi:10.1177/030437540102600201.

Hindess, B. 2004. Liberalism - What's in a Name, [w:] Global Governmentality: Governing International Spaces, W. Larner, W. Walters (red.), Routledge, Londyn.

Hindess, B. 2005. Politics as Government. Michel's Foucault Analysis of Political Reason, "Alternatives", t. 30, nr 4, http://dx.doi.org/doi:10.1177/030437540503000401.

Jessop, B. 2006. From Micro-Powers to Governmentality Foucault's Work on Statehood, State Formation, Statecraft and State Power, "Political Geography", t. 26, nr 1, http://dx.doi.org/10.1016/j.polgeo.2006.08.002.

Kienscherf, M. 2013. US Domestic and International Regimes of Security. Pacifying the Globe, Security and Homeland, Routledge, Abington.

Mbembe, A. 2003. Necropolitics, "Political Culture", t. 15, nr 1.

Medovoi, L. 2007. Global Society Must Be Defended. Biopolitics without Boundaries, "Social Text", t. 25, nr 2, http://dx.doi.org/doi:10.1215/01642472-2006-027.

Muller, B. 2008. Governing trough Risk at the Canada/US Border: Liberty, Security, Technology, Border Policy Research Institute, Working Paper no 2.

Muller, B. 2009. Borders, Risks, Exclusions, "Studies in Social Justice", t. 3, nr 1.

Neocleous, M. 2008. Critique of Security, Edinburg University Press, Edynburg.

Purcell, M., Nevins, J. 2005. Pushing the Boundary: State Restructuring, State Theory and the Case of US-Mexico Border Enforcement in 1990s., "Political Geography", t. 24, nr 2, http://dx.doi.org/doi:10.1016/j.polgeo.2004.09.015.

Reid, J. 2006. The Biopolitics of the War on Terror. Life Struggles, Liberal Modernity and the Defence of Logistical Societies, Manchester University Press, Manchester.

Roberts, D. 2010. Global Governance and Biopolitics. Regulating Human Security, Zed Books, Londyn.

Salter, M. 2006. The Global Visa Regime and the Political Technologies of the International Self: Borders, Bodies, Biopolitics, “Alternatives", t. 31, nr 2, http://dx.doi.org/doi:10.1177/030437540603100203.

Salter, M. 2008. Imagining Numbers: Quantification and Aviation Security, "Security Dialogue", t. 39, nr 2-3, http://dx.doi.org/doi:10.1177/0967010608088777.

Schmitt, C. 2007. The Concept of the Political, The University Chicago Press, Chicago.

Singh, R. 2015. 'Defensive Liberal Wars': The Global War on Terror and the Return of Illiberalism in American Foreign Policy, "Revista de Sociologia e Politica", t. 23, nr 53, http://dx.doi.org/10.1590/1678-987315235306.

Smart Border Declaration of 2001, http://www.legislationline.org/documents/id/7543 (dostęp: 23.11.2015).

Sparke, M.B. 2006. A Neoliberal Nexus: Economy, Security and the Biopolitics of Citizenship on the Border, "Political Geography", t. 25, nr 2, http://dx.doi.org/doi:10.1016/j.polgeo.2005.10.002.

U.S. Customs and Border Protection, Trusted Traveler Programs, https://www.cbp.gov/travel/trusted-traveler-programs (dostęp: 23.11.2015).

U.S. Department of State, U.S. - Canada Smart Border/30 Point Action Plan Update, http://2001-2009. state.gov/p/wha/rls/fs/18128.htm (dostęp: 23.11.2015).

United States 2002, The National Security Strategy of the United States of America, http://www.state.gov/ documents/organization/63562.pdf (dostęp: 22.11.2015). 


\begin{abstract}
The article analyzes the spaces of security produced by the American administration after $9 / 11$ through the lenses of the concept of biopolitics, as delivered by French philosopher Michel Foucault. The main aim of this article is to reveal interconnections between the population-centric notion of biopolitcs, practices of liberal governmentality and security per se. As a tangible example of that linkage there will be introduced the process of borders enhancement, which operating through the biometric technologies of risk management produces the so-called Smart Borders. In the biopolitical context, the result of Smart Borders was the reduction of negative elements in the circulation of goods in the security space.
\end{abstract}

Key words: biopolitics, Global War on Terror, Smart Borders, securitization of borders

BIOGRAM

Magdalena M. Kania, doktorantka w Zakładzie Bezpieczeństwa Narodowego Uniwersytetu Jagiellońskiego w Krakowie, absolwentka stosunków międzynarodowych na UJ oraz studentka prawa. Kontakt e-mail: magdalena.maria.kania@gmail.com. 